lished and accepted technique. However, it does have an inherent disadvantage in that there is a wide variation in the individual patient's response to oxytocin. Refined infusion pumps are thus required (MacVicar and Howie, 1967; Francis, Turnbull, and Thomas, 1970) or, if the Syntocinon is given in dilute solution, manual adjustment of the drip rate is wasteful of valuable nursing time. Even with these techniques, there is still an induction failure rate, probably owing to failure of the uterus to respond satisfactorily to exogenous oxytocin in some instances (MacVicar, 1971).

In the series described, when a combined prostaglandin $\mathrm{E}_{2}$ and oxytocin infusion was administered the range of oxytocin escalation was about a quarter $(24 \%)$ of that which was required when the drug was infused alone. Also, from the comparative results of the series, on average the prostaglandin component of the combined infusion was apparently equivalent to a constant base line infusion of 10 units of oxytocin in $500 \mathrm{ml}$ of solution at about 41 drops a minute $(55 \mathrm{mU} / \mathrm{min})$. We suggest that the simultaneous combined regimen is acceptable and enables adequate uterine stimulation to be achieved with a greatly reduced range of oxytocin escalation. The reduction in the total amount of oxytocin infused will tend to minimize the antidiuretic effect which may possibly be associated with oxytocin infusion (Liggins, 1962). Finally, the total duration of labour may also be reduced when the combined infusion is used.

There is accumulating evidence to suggest that prostaglandin and oxytocin are both involved in the normal physiological process of labour (Brummer, 1971; Gillespie, 1972; Gillespie, Brummer, and Chard, 1972). It remains to be evaluated whether this combined regimen will reduce further the dwindling proportion of patients in whom induction of labour by amniotomy and oxytocic infusion is unduly prolonged or is totally unsuccessful.

\section{References}

Brummer, H. C. (1971). Fournal of Obstetrics and Gynaecology of the British Commonwealth, 78, 305.

Francis, J. G., Turnbull, A. C., and Thomas, F. F. (1970). Fournal of Obstetrics and Gynaecology of the British Commonwealth, 77, 594.

Gillespie, A. (1972). British Medical fournal, 1, 150. Gillespie, A., Brummer, H. C., and Chard, T. (1972). British Medical

Liggins, G. C. (1962). Fournal of Obstetrics and Gynaecology of the British Commonwealth, 69, 277.

MacVicar, J. (1971). Fournal of Obstetrics and Gynaecology of the British Commonwealth, 78, 1007.

MacVicar, J., and Howie, P. W. (1967). Lancet, 2, 1339.

\title{
Herpesvirus hominis Infection in Patients with Myeloproliferative and Lymphoproliferative Disorders
}

\author{
D. L. ASTON, A. COHEN, MARGARET A. SPINDLER
}

British Medical fournal, 1972, 4, 462-465

\begin{abstract}
Summary
Infection with Herpesvirus hominis, often associated with oral ulceration, was found to be more frequent in patients with myeloproliferative and lymphoproliferative disorders than in normal populations or patients with other diseases. This increased frequency was not associated with any deficiency of the humoral antibody response, suggesting a possible impairment of cellmediated immunity. The otherwise untreatable oral lesions appeared to respond effectively to local irradiation.
\end{abstract}

\section{Introduction}

The frequent occurrence of severe oral ulceration in patients suffering from various types of leukaemia and lymphoma prompted an investigation into the aetiology of the oral lesions. Clinical impressions suggested an herpetic origin and others have commented on the frequency of herpetic infections in patients with myeloproliferative and lymphoproliferative disorders (Stewart, 1950; Ultman et al., 1959; Muller et al., 1972) few patients, however, have been subjected to virological investigations. In the present study virological investigations were used to establish the aetiological role of Herpesvirus

Department of Clinical Haematology, University College Hospital, London WC1E 6AU

D. L. ASTON, M.B., B.CHIR., Registrar

Department of Bacteriology, University College Hospital Medical School, London WC1E 6JJ

A. COHEN, D.M., F.R.C.PATH., Reader in Virology

MARGARET A. SPINDLER, Senior Technician hominis (herpes simplex virus) in the pathogenesis of the lesions observed. The study was further extended to determine the frequency of herpetic infection in patients with myeloproliferative and lymphoproliferative disorders, and to relate any increase to an abnormality of the humoral immune response.

\section{Patients and Methods}

A total of 69 patients attending a haematology clinic for a myeloproliferative or lymphoproliferative disorder, of whom 15 had developed oral ulcerative lesions, were investigated for evidence of infection with $H$. hominis. For the purpose of this investigation 579 hospital inpatients who had had throat swabs taken for virological investigation of respiratory infections between 1966 and 1970 served as control subjects.

\section{TREATMENT}

The drug regimens for the myeloproliferative and lymphoproliferative disorders were conventional dosages of appropriate combinations of the accepted antimitotic agents.

Oral and perioral lesions were treated by local irradiation using a $100 \mathrm{kV}$ superficial therapy $x$-ray apparatus delivering 100-200 rads. The treatment was repeated two or three times on alternate days. A few patients who were too ill to leave the ward received a similar dose of radiation from a radioactive strontium plaque applied to the ulcerated surface.

\section{SPECIMENS}

Two throat swabs were taken from each patient undergoing investigation and a further swab was taken from any oral ulcerative lesion. Swabs moistened with transport medium were rubbed over the lesion or over the posterior pharyngeal wall and faucial areas and were then expressed into $1 \mathrm{ml}$ of transport 
medium which consisted of Hank's balanced salt solution supplemented with $10 \%$ bovine serum albumin and added antibiotics. Normally specimens were transferred to the laboratory on the day of collection for inoculation, but occasionally specimens were stored at $-70^{\circ} \mathrm{C}$ until appropriate cell cultures became available.

\section{CELLS AND MEDIA}

HeLa.-HeLa cells were obtained from Dr. K. Apostolov (Wellcome Foundation Research Laboratories). Monolayer cultures were grown in test-tubes on Eagle's minimal essential medium supplemented with $10 \%$ calf serum and antibiotics (penicillin 100 units/ $\mu \mathrm{l}$,, streptomycin $100 \mu \mathrm{g} / \mu \mathrm{l}$.). After infection the cells were maintained on Eagle's minimal essential medium supplemented with $1 \%$ fetal calf serum and antibiotics with added amphotericin B $(5 \mu \mathrm{g} / \mu \mathrm{l}$.).

Human Embryo Lung.-This diploid fibroblast line was initiated from human embryo lungs obtained from the tissue bank of the Royal Marsden Hospital, London. Monolayer cultures were grown from the 6th-20th passage in test-tubes on Eagle's minimal essential medium supplemented with $10 \%$ fetal calf serum, $1 \%$ glutamine, and antibiotics. After infection, the cells were maintained on Eagle's minimal essential medium supplemented with $1 \%$ fetal calf serum, $1 \%$ glutamine, and antibiotics with added amphotericin B.

Monkey Kidney.-These were obtained weekly from the Medical Research Council Laboratories, Hampstead, London, by courtesy of Dr. F. Perkins. Secondary monolayer cultures were grown in test-tubes on Hank's balanced salt solution supplemented with $2 \%$ calf serum, $5 \%$ lactalbumin hydrolysate, and antibiotics with added amphotericin B.

Chick Embryos.-Chick embryos incubated at $37.5^{\circ} \mathrm{C}$ for 11-12 days were used for chorioallantoic membrane inoculation. After inoculation the eggs were incubated at $35^{\circ} \mathrm{C}$ for three days when the chorioallantoic membranes were harvested and examined for typical herpetic pock lesions.

Antiserum to $H$. hominis.-Neutralizing antiserum was obtained from the Standards Laboratory for Serological Reagents, Central Public Health Laboratory, Colindale, London.

\section{ISOLATION AND IDENTIFICATION OF H. HOMINIS}

On receipt, penicillin 100 units/ $\mu \mathrm{l}$, streptomycin $100 \mu \mathrm{g} / \mu \mathrm{l}$, and amphotericin B $5 \mu \mathrm{g} / \mu \mathrm{l}$ were added to each specimen, which was then allowed to stand at $4^{\circ} \mathrm{C}$ for 30 minutes or more. Inocula of $0.1 \mathrm{ml}$ were then introduced into two tubes each of HeLa, human embryo lung, and monkey kidney cells which were incubated on a rotating drum at $37^{\circ} \mathrm{C}$ and subcultured every seven days up to a maximum of 21 days in parallel with appropriate uninfected controls. A $0 \cdot 2-\mathrm{ml}$ sample of each specimen was simultaneously inoculated on to the chorioallantoic membrane of two 11-12 day old chick embryos. Virus from specimens producing a cytopathic effect in HeLa or human embryo lung but not in monkey kidney cells was identified as $H$. hominis if typical herpetic pock lesions were found on chorioallantoic membrane after primary or secondary passage, and if the cytopathic effect was neutralized by specific antiserum to $H$. hominis.

\section{NEUTRALIZATION TESTS}

Virus Identification.-Harvests from cultures positive for cytopathic effect were serially diluted from $1: 2$ to $1: 1,000$ either in typing antiserum to $H$. hominis diluted 1:50 or with saline as a control. Dilutions were held at room temperature for 30 minutes when $0 \cdot 1-\mathrm{ml}$ inocula from each dilution were introduced into two monolayer tube cultures of HeLa cells. Neutralization of the cytopathic effect by the typing antiserum confirmed the identification of the virus.

Titration of Serum Antibody.-For titration of antibody to $H$. hominis in the patients' sera serial dilutions of serum were mixed with an equal volume of a standard strain of $H$. hominis adjusted to contain $10^{2} \mathrm{TCID}_{50} / 0 \cdot 1 \mathrm{ml}$. Mixtures were held at room temperature for 30 minutes when $0 \cdot 2-\mathrm{ml}$ inocula from each mixture were introduced into two monolayer tube cultures of HeLa cells. The dilution of serum which neutralized the cytopathic effect of the challenge virus by $50 \%$ after five days' incubation was taken to represent the neutralizing titre. To preserve low titre antibodies sera were not heat-inactivated (Yoshino and Toniguchi, 1964, 1966; Heineman, 1967) but normal and immune rabbit sera were included in every experiment to exclude non-specific serum inhibitors of $H$. hominis.

\section{Results}

Twenty-four strains of $H$. hominis were isolated from 154 specimens submitted for investigation. The number of positive isolations obtained by each technique used for primary isolation is shown in Table I. HeLa cells were slightly more susceptible to

TABLE I-Tissue Susceptibility to H. hominis on Primary Isolation

\begin{tabular}{l|l|c}
\hline \multicolumn{2}{c|}{ Mode of Isolation } & $\begin{array}{c}\text { No. Positive from } \\
154 \text { Specimens }\end{array}$ \\
\hline Cell culture & $\left\{\begin{array}{l}\text { HeLa } \\
\text { Chick embryo }\end{array}\right.$ & $\begin{array}{l}24 \\
\text { Monkan embryo lung } \\
\text { Chorioallantoic membrane }\end{array}$ \\
\hline
\end{tabular}

$H$. hominis infection than human embryo lung, and chick embryo chorioallantoic membrane was the least sensitive tissue. Primary isolation in tissue cultures of susceptible cells is, therefore, preferable to inoculation on to chick embryo chorioallantoic membrane.

\section{INCIDENCE OF HERPETIC INFECTION}

Sixty-nine patients with a myeloproliferative or lymphoproliferative disorder were investigated, and the results are summarized in Table II. Of these, $H$. hominis was isolated from 11 $(16 \%)$. In contrast, the virus was isolated from only $2 \%$ of hospital inpatients serving as the control population, a frequency of isolation which agrees with the average incidence found in populations without clinical evidence of herpetic infection (Table III). The relation between the occurrence of lesions in patients with myeloproliferative or lymphoproliferative disorders and the isolation of $H$. hominis is also included in Table II. Of 15 patients who exhibited lesions, virus was isolated from the lesion swab of $8(53 \%)$ but only $5.5 \%$ of patients without lesions yielded virus. This suggests that herpetic infection in the

TABLE II-Incidence of Herpetic Infection

\begin{tabular}{|c|c|c|c|c|c|c|}
\hline \multicolumn{4}{|c|}{ Category of Patients } & $\begin{array}{l}\text { Total } \\
\text { No. }\end{array}$ & $\begin{array}{l}\text { No. of Virus } \\
\text { Isolations }\end{array}$ & $\begin{array}{l}\text { Per cent. } \\
\text { Positive }\end{array}$ \\
\hline \multicolumn{7}{|c|}{$\begin{array}{l}\text { Myeloproliferative or Lymphoproliferative } \\
\text { disorder: }\end{array}$} \\
\hline $\begin{array}{ll}\text { All patients } & \ldots \\
\text { With lesions } & \ldots\end{array}$ & $\cdots$ & .. & . & $\begin{array}{l}69 \\
15\end{array}$ & 11 & $\begin{array}{l}16 \\
53\end{array}$ \\
\hline $\begin{array}{l}\text { With lesions } \\
\text { Without lesions }\end{array}$ & $\because$ & $\because$ & $\because$ & 54 & 3 & 5.5 \\
\hline \multirow{2}{*}{\multicolumn{4}{|c|}{$\begin{array}{l}\text { Control subjects: } \\
\text { Hospital inpatients }\end{array}$}} & & & \\
\hline & & & & 579 & 12 & $2 \cdot 0$ \\
\hline
\end{tabular}

TABLE III-Herpesvirus Isolations in Normal Populations

\begin{tabular}{l|l|c|c|c}
\hline \multicolumn{1}{c|}{\begin{tabular}{l|c} 
Study Reference \\
Buddingh et al. (1953)
\end{tabular}} & Population & $\begin{array}{c}\text { Total } \\
\text { No. }\end{array}$ & $\begin{array}{c}\text { No. of Virus } \\
\text { Isolations }\end{array}$ & $\begin{array}{c}\text { Per cent. } \\
\text { Positive }\end{array}$ \\
\hline $\begin{array}{l}\text { Lindgren } \text { et al. (1968) } \\
\begin{array}{l}\text { Hope-Simpson and ages } \\
\text { Higgins (1969) }\end{array}\end{array}$ & P 15 years & 571 & 39 & $7 \cdot 0$ \\
All ages & 418 & 21 & $2 \cdot 4$ \\
All ages & 79 & 1 & $1 \cdot 0$ \\
\hline
\end{tabular}


patients under investigation is usually associated with clinical manifestation of disease. Moreover, the high frequency of virus isolation in the presence of lesions makes their herpetic aetiology well-founded. Our success in isolating virus from patients with lesions of herpetic origin compares favourably with the results described by Douglas and Couch (1970) who isolated virus from $24 \cdot 1 \%$ of specimens of oral secretions collected from patients with herpetic lesions. Prospective studies were carried out on two patients who entered the study without lesions but who yielded virus on routine swabbing. Neither developed lesions on follow-up, and one was later shown to be free of virus. Of 59 patients who entered the study without lesions and were negative for virus, only one yielded virus later during the course of observation with the development of a lesion, but four other patients who later developed lesions remained negative for virus.

Herpetic infection is found in patients with various types of myeloproliferative or lymphoproliferative disorder and is not characteristic of any particular type (Table IV).

TABLE IV-Herpetic Infection in Myeloproliferative and Lymphoproliferative Disorders

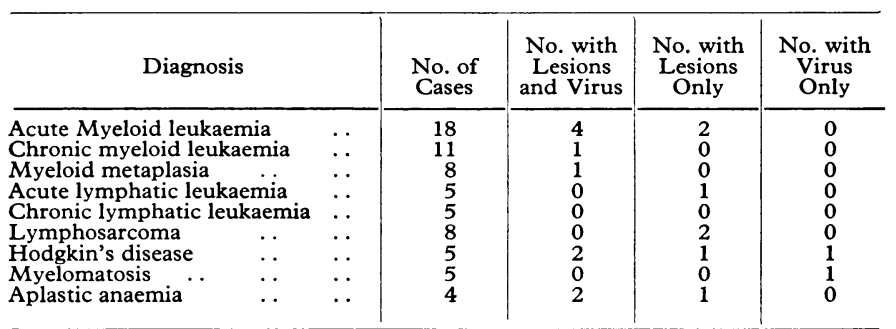

\section{EFFECT OF LOCAL IRRADIATION}

Nine patients with severe oral ulceration of one to six weeks' duration were treated by local irradiation and virus was recovered from five of these before treatment began. Symptoms were relieved in eight patients within $24-48$ hours, and healing followed in the next few days. Of the five patients from whom virus was recovered before irradiation, three failed to yield virus afterwards, one died, and one, the only patient who failed to respond to treatment, continued to excrete virus.

\section{PROGNOSIS AFTER HERPETIC INFECTION}

It became apparent that survival after virological or clinical evidence of herpetic infection was short, although the lesions

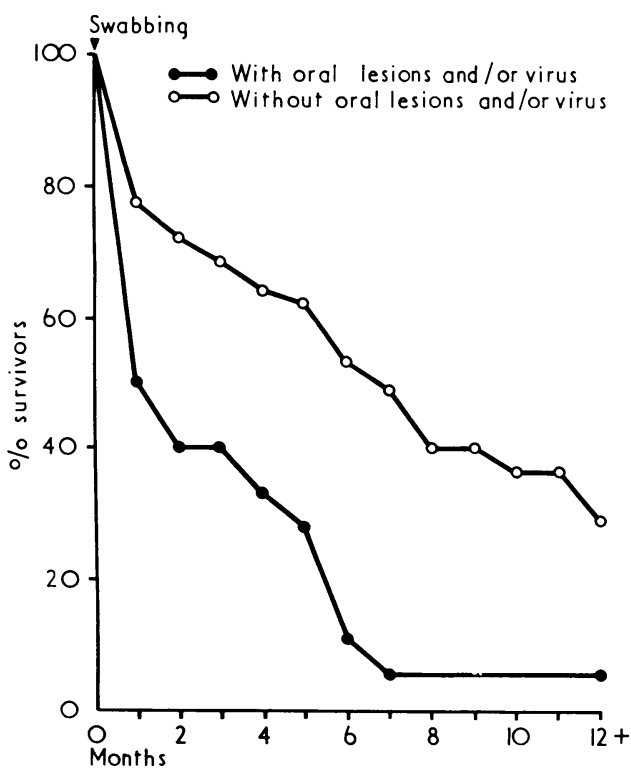

Cumulative survival rates in patients with myeloproliferative and lymphoproliferative disorders. in most patients had healed after local irradiation therapy before death. Indeed, eight of 16 patients died within one month of herpetic infection being diagnosed. The survival rates of infected and uninfected patients after swabbing for evidence of viral infection are compared in the Chart. These results indicate that herpetic infection is a terminal or near-terminal event in this group of patients and is indicative of a poor prognosis. This finding agrees with that of Casazza et al. (1966) who observed an increased incidence of infectious complications in the terminal phase of lymphomas.

\section{ANTIBODY RESPONSE TO INFECTION}

The high incidence of $H$. hominis infection in patients with myeloproliferative and lymphoproliferative disorders raised the question of some immunodeficiency as a possible cause for the decline in host resistance to infection. This question was of particular importance since all the patients had been treated at one time or another with immunosuppressive drugs. To assess the role of serum antibody in host resistance and the pathogenesis of herpetic infection the level of neutralizing antibody to $H$. hominis in sera from patients and control subjects was investigated. Antibodies to the virus can be found in up to $90 \%$ of adults in normal populations, usually as a result of primary herpetic clinical or subclinical infection often acquired in childhood (Buddingh et al., 1953; Yoshino et al., 1962; Smith et al., 1967). A four-fold rise in the level of serum antibody is characteristic of a primary infection but patients with recurrent herpetic infections usually exhibit a permanently high level of antibody (Scott et al., 1952; Scott, 1957). Sera from various categories of patients and from control subjects were tested for neutralizing antibody to $H$. hominis, and the results are summarized in Table V. Sera from patients with viral or

TABLE v-Antibody Levels in Acute-phase Sera

\begin{tabular}{|c|c|c|c|c|c|c|c|}
\hline \multirow{2}{*}{\multicolumn{3}{|c|}{ Category of Patients }} & \multirow{2}{*}{ No. } & \multicolumn{3}{|c|}{ Titre } & \multirow{2}{*}{$\begin{array}{l}\text { Per cent. } \\
\text { with Titre } \\
\quad>10\end{array}$} \\
\hline & & & & $<10$ & $10-50$ & $>50$ & \\
\hline \multicolumn{3}{|c|}{$\begin{array}{l}\text { Myeloproliferative or } \\
\text { Lymphoproliferative } \\
\text { disorders: }\end{array}$} & 16 & 3 & 6 & 7 & 81 \\
\hline $\begin{array}{l}\text { Without lesions } \\
\text { Control subjects ( } \\
\text { inpatients): }\end{array}$ & $\begin{array}{l}\text { or virus } \\
\text { hospital }\end{array}$ & $\because$ & 39 & 11 & 14 & 14 & 72 \\
\hline $\begin{array}{l}\text { With virus } \\
\text { Without virus }\end{array}$ & $\begin{array}{ll}. & \ldots \\
. & \ldots\end{array}$ & $\begin{array}{l}\cdots \\
\cdots\end{array}$ & $\begin{array}{r}5 \\
56\end{array}$ & $\begin{array}{r}4 \\
28\end{array}$ & $\begin{array}{r}1 \\
19\end{array}$ & $\begin{array}{l}0 \\
9\end{array}$ & $\begin{array}{l}20 \\
50\end{array}$ \\
\hline
\end{tabular}

clinical evidence of herpetic infection showed no evidence of gross antibody deficiency compared with sera from control subjects with $H$. hominis infection. Similarly, no deficiency of antibody to the virus was evident in the sera of patients or control subjects without any overt evidence of herpetic infection. The high level of herpetic infection in patients with myeloproliferative and lymphoproliferative disorders is not, therefore, a consequence of their failure to produce antibody to $H$. hominis. Serial serum specimens obtained from six patients and three control subjects with herpetic infection showed a significant rise in titre of antibody to $H$. hominis in only two patients and one control subject, which suggests that the infections studied were mainly of the recurrent type.

\section{Discussion}

Our findings leave little doubt that the oral ulceration observed in patients with myeloproliferative and lymphoproliferative disorders is the result of infection with $\mathrm{H}$. hominis. A higher rate of virus isolation may have been possible with more detailed attention to the timing and frequency of specimen collection and to the isolation techniques used (Douglas and Couch, 1970; Lindgren et al., 1968). It is, therefore, unlikely that many, if any of the lesions seen were of other than viral aetiology, particularly 
as most of the patients were receiving prophylactic or therapeutic doses of nystatin.

About half the patients in the series had received treatment with daunorubicin or cytarabine on at least one occasion. Both these cytotoxic drugs are known to inhibit herpesvirus replication (Cohen et al., 1969; Underwood, 1962; Underwood et al., 1964), so that enhancement of herpetic infection in these patients is surprising, particularly as seven out of 18 patients who showed evidence of herpetic infection had received treatment with one of these drugs in the preceding month.

Cutaneous and perioral herpetic lesions have been successfully treated by local application of idoxuridine preparations (Muller et al., 1972; Juel-Jensen and MacCallum, 1964, 1965) but the treatment requires frequent applications and is not generally applicable to intraoral lesions. Local irradiation proved to be a more practical and convenient method of treatment, which was very effective in promoting rapid healing of the otherwise intractable oral lesions. Its success may be due to direct inactivation of the virus, and it is of interest that virus was not recovered from the few swabs available after local irradiation.

Myeloproliferative and lymphoproliferative disorders are often associated with abnormalities of the immune response (Aisenberg, 1962; Miller, 1962), and the high dosages of irradiation and many of the drugs that the present patients received are immunosuppressive. Although a relation between the high incidence of herpetic infection and some deficiency of the immune response was, therefore, possible our findings have failed to yield evidence of any gross deficiency in antibody production. Serological investigation differentiates between the two main types of herpetic infection; primary infections which occur in non-immunes, and recurrent infections which occur in those with persistently high levels of antibody. After primary infection, which may be clinical or subclinical and is usually acquired in childhood, the virus is believed to remain latent in the tissues (Burnet and Williams, 1939; Paine, 1964). Reactivation of the virus in some patients from time to time leads to periodic recurrent infection. Since characteristically high levels of antibody were observed in acute phase sera from most of the present patients with clinical or virological evidence of infection, and no rise in titre was seen in sera from four out of six patients from whom serial specimens were available, the herpetic syndromes observed were presumed to be mainly of the recurrent type.

The failure of serum neutralizing antibody to affect the development of the herpetic lesions suggests that some deficiency of cell-mediated rather than humoral immunity is responsible for their frequent occurrence in these patients. Indeed, the results of Wilton et al. (1972) suggest that susceptibility to recurrent herpetic infection is related to impairment of lymphocyte activity (reflected by impaired inhibition of macrophage migration and lymphocyte cytotoxicity) rather than to any impairment of lymphocyte sensitization or antibody production. Moreover, recovery from herpetic infection is associated with delayed-type hypersensitivity to one of the soluble antigens of $H$. hominis (Nagler, 1944; Rose and Molloy, 1947). The occurrence of severe herpetic lesions in the presence of adequate titres of circulating antibody in patients maintained on large doses of immunosuppressive agents after organ transplantation and in patients with Wiskott-Aldrich syndrome lends support to this hypothesis (Montgomerie et al., 1969; St. Geme et al., 1965). Clearly, further investigations of cell-mediated immunity in patients with myeloproliferative and lymphoproliferative disorders are indicated.

In this report no attempt has been made to differentiate the effect of the disease from that of its treatment in contributing to the increased frequency of herpetic infections observed. Nor was it possible to do so, as herpetic infection usually occurred during or shortly after an active phase of the disease which necessitated treatment. It may be noted, however, that in the series of Hersh et al. (1965) $70 \%$ of patients with acute leukaemia died of infectious conditions whether they had received antimitotic therapy or not.

Thanks are due to Professor T. A. J. Prankerd for suggesting this investigation, for allowing access to the patients under his care, and for his continued interest.

We thank Professor G. Belyavin for his support and encouragement, and Dr. E. W. Emery and Dr. N. Godlee for supervising the local irradiation therapy.

\section{References}

Aisenberg, A. C. (1962). Fournal of Clinical Investigation, 41, 1964.

Buddingh, G. J., Schrum, D. I., Lanier, J. C., and Guichy, D. J. (1953). Pediatrics, 11, 595

Burnet, F. M., and Williams, S. W. (1939). Medical fournal of Australia, 1,637 .

Casazza, A. R., Duvall, C. P., and Carbone, P. P. (1966). Fournal of the American Medical Association, 197, 710 .

Cohen, A., Harley, E. H., and Rees, K. R. (1969). Nature, 222, 36.

Douglas, R. G., jun., and Couch, R. B. (1970). Fournal of Immunology, 104, 289.

Heineman, H. S. (1967). fournal of Immunology, 99, 214.

Hersh, E. M., Bodey, G. P., Nies, B. A., and Freireich, E. J. (1965). fournal of the American Medical Association, 193, 105

Hope-Simpson, R. E., and Higgins, P. G. (1969). In Progress in Medical Virology, ed. J. C. Melnick, vol. 11. Basel, Karger

Juel-Jensen, B. E., and MacCallum, F. O. (1964). British Medical fournal, $2,987$.

Juel-Jensen, B. E., and MacCallum, F. O. (1965). British Medical fournal, 1,901 .

Lindgren, K. M., Douglas, R. G., jun., and Couch, R. B. (1968). New England fournal of Medicine, 278, 517 .

Miller, D. G. (1962). Annals of Internal Medicine, 57, 703.

Montgomerie, J. Z., Becroft, D. M. O., Croxson, M. C., Doak, P. B., and North, J. D. K. (1969). Lancet, 2, 867.

Muller, S. A., Herrmann, E. C., jun., and Winkelmann, R. K. (1972). American fournal of Medicine, 52, 102 .

American fournal of Medicine, 52, 102.
Nagler, F. P. O. (1944). Fournal of Immunology, 48, 213.

Paine, T. F., jun. (1964). Bacteriological Reviews, 28, 472.

Rose, H. M., and Molloy, E. (1947). Fournal of Immunology, 56, 287.

Scott, T. F. McN. (1957). American fournal of Ophthalmology, 43, 134.

Scott, T. F. McN., Coriell, L., Blank, H., and Burgoon, C. F. (1952). Fournal of Pediatrics, 41, 835.

Smith, I. W., Peutherer, J. F., and MacCallum, F. O. (1967). Fournal of Hygiene, 65, 395.

Stewart, R. A. (1950). Archives of Dermatology, 61, 508.

St. Geme, J. W., jun., Prince, J. T., Burke, B. A., Good, R. A., and Krivit, W. (1965). New England Fournal of Medicine, 273, 229.

Underwood, G. E. (1962). Proceedings of the Society for Experimental Biology and Medicine, 111, 660 .

Underwood, G. E., Wisner, C. A., and Weed, S. D. (1964). Archives of

Ophthalmology, 72, 505.
Ultman, J. E., Fish, W., Osserman, E., and Gellhom, A. (1959). Annals of Internal Medicine, $\mathbf{5 1}, 501$.

Wilton, J. M. A., Ivanyi, L., and Lehner, T. (1972). British Medical fournal, $1,723$.

Yoshino, K., and Toniguchi, S. (1964). Virology, 22, 193.

Yoshino, K., and Toniguchi, S. (1966). Fournal of Immunology, 96, 196 Yoshino, K., et al. (1962). Fapanese fournal of Medical Science and Biology, 